\title{
Ecological assessment of East Hammar marsh, Iraq using a number of ecological guides
}

\author{
Abdul-Razak M. Mohamed, Azhar A. Al-Saboonchi and Fadia K. Raadi \\ Department of Fisheries and Marine Resources, College of Agriculture, \\ Basrah University, Iraq \\ abdul19532001@yahoo.com
}

\begin{abstract}
The ecological status of the East Hammar marsh was evaluated by using a number of ecological guides: water quality index (WQI), Carlson trophic state index (TSI) and fish integrated biological index (F-IBI) during the period from November 2012 to October 2013. The results revealed that the annual value of WQI varied from 51.1 (marginal) for historical data before desiccation to 67.8 (fair) for data after inundation. The marsh was evaluated to be mesotrophic (TSI=42.0). IBI scores were calculated from 16 separate assemblage metrics based on the fish species richness, species composition and trophic guilds. The ecological status of the marsh was found to be fair $(\mathrm{F}-\mathrm{IBI}=47.7)$ and was slightly better than the status of the marsh after 2-4 years of restoration activities. The rather low improvement in the situation of the marsh indicates that the environment is still fragile and requires the allocation of water share from the Tigris and Euphrates rivers to restore marsh normality.
\end{abstract}

Key words: Water quality index, trophic state index, fish integrated biological index, Iraqi marshes

\section{Introduction}

Wetlands include a wide variety of habitats such as marshes, peat lands, floodplains, rivers and lakes, and coastal areas such as salt marshes, mangroves, and sea grass beds, but also coral reefs and other marine areas no deeper than six meters at low tide, as well as human-made wetlands such as waste-water treatment ponds and reservoirs (Ramsar Convention Secretariat 2013).

The Southern Marshes in Iraq of a wider wet land in southwest Asia, covering an area of more than $15,000 \mathrm{~km}^{2}$ and is characterized by a lid vegetarian dense and therefore constitute a natural shelters for many of the special birds and marine settlement, fish, buffalo, neighborhoods and other aquatic biology is characterized by agricultural and handicraft of its products, which are a source of live is important for a large number of residents of the area over the centuries (Partow, 2001). Drainage processes of the southern marshlands started in the early 1990 s by diverted the major rivers away from the marshes, and led to substantial loss of native aquatic flora and fauna wellknown for a long period as marsh biota of southern Iraq. In 2002, 85\% of permanent marshes described in 1973 had been environmentally destroyed (Richardson and Hussain 2006). Since 2003, great efforts have been made to restore the marshes and revive the wetlands environment. As of August 2007, the marshes had recovered almost $58 \%$ of their former area in 1972 according to UNEP/IMOS (2007).

Several studies have been focus on describe water quality and the fish assemblages in the southern marshes since inundation in 2003 (ARID, 2006; Hussain et al., 2009; Mohamed et al., 2008, 2012, 2014). Some works have been carried out attempting to evaluate water quality change as result of environmental alteration in the marshes by using Water Quality Index, WQI 
or water characteristics (Al-Saboonchi et al., 2011; Al-Kenzawi et al., 2011) or fish structure changes in the marshes by applying the Index of Biotic Integrity, IBI (Al-Shamary, 2008; Mohamed and Hussain 2012a; Mohamed 2014a, b).

During the last years, the environment of East Hammar marsh was suffered from various problems amongst them the fluctuation in water levels and increasing in the salinity due to different reasons such as the decline in the discharge rates of the Tigris and Euphrates Rivers as a result of several hydrological projects constructed in the riparian countries (Partow, 2001) and the diversion of Karun River into Iranian terrene (Hameed and Aljorany 2011), which used to be an important source of fresh water to the Shatt Al-Arab, serving as a barrier to reduce the progress of salty water from the Gulf upstream (Hassan et al., 2011).

Therefore, the objective of this work was to evaluate the restored environment of East Hammar marsh by applying the water quality index, the trophic state index, the ecological indices of fish community and the index of biotic integrity of fish.

\section{Materials and methods}

Al-Hammar marsh is the biggest southern marshes extended in two provinces (Basrah and Nasiriyah). It is approximately $120 \mathrm{~km}$ long and $25 \mathrm{~km}$ wide. Maximum water depth in the marsh ranges from 1.8-3.0 $\mathrm{m}$. The marsh narrowed about the middle consequently it could be divided roughly in two parts west and east. After inundation in 2003, large areas of A1Hammar were reflooded by riverine water. Recently west Al-Hammar marsh is fed primarily from tributaries of Euphrates River and from the Main Outfall Drainage (MOD) channel, but the eastern part get a considerable amount of water from Shatt Al-Arab river, groundwater recharge is another source of replenishment.

To execute the present study three sites were selected in the East Hammar marsh (Fig. 1), based on the nature of the areas. Harer site

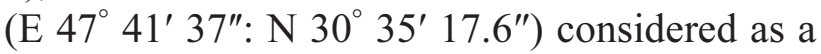
tidal channel marsh environment, Salal site (E $\left.47^{\circ} 39^{\prime} 19.7^{\prime \prime}: \mathrm{N} 30^{\circ} 38^{\prime} 17.2^{\prime \prime}\right)$ and Burkah site

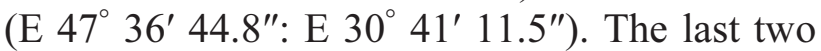
sites were previously desiccated, but they are now tidal open shallow water with scattered islands of Typha domingensis and Myrophyllum verticillatum.

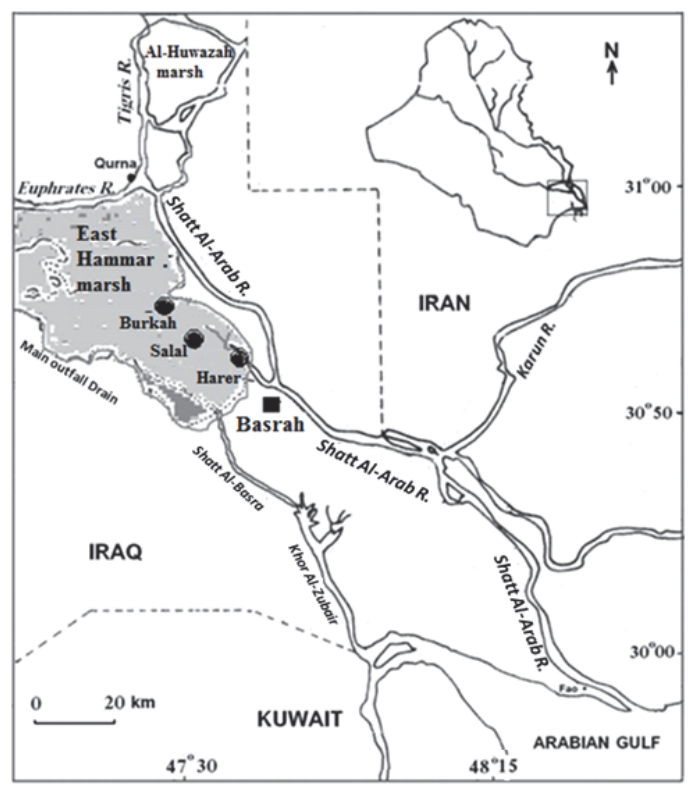

Fig.1. Map of southern of Iraq showing the sampling sites in the East Hammar marsh

Water sample was collected monthly from the three sampling sites immediately prior to fish sampling during November 2012- October 2013. Water temperature, salinity, dissolved oxygen, and $\mathrm{pH}$ were measured in situ using YSI portable instrument model 556 MPS. The following factors selected as water quality parameters were measured using the methods described for each factor as follows. Transparency was evaluated by extinction method using the Secchi disc. Reactive nitrate 
and orthophosphate were analyzed by Strickland and Parsons Modification method and Murphy and Riley method, respectively (Parson et al., 1984), whereas total phosphate was determined by Ascorbic acid method (APHA, 2005) and chlorophyll a was measured according to Lind (1979) using spectrophotometer model LKB 4050 .

In this study, the CCME Water Quality Index (CCME, 1999) was applied for the East Hammar marsh. The study period was divided into two seasons, dry season (May to October) and wet season (November to April), and the results were tested with two types of criteria: first, historical published data before desiccation (Maulood et al., 1979; Al-Lami, 1986; Al-Araji, 1988; Mohamed and Barak 1988) and the second was historical published data after inundation (ARDI, 2006; Tahir et al., 2008). For this analysis, index scores were determined for seven constituents: water temperature, $\mathrm{pH}$, transparency, dissolved oxygen, salinity, reactive nitrates and orthophosphate. The computed WQI values could be classified as 95$100=$ excellent; $80-94=$ good; $65-79=$ fair; 45 $64=$ marginal and $0-44=$ poor $($ CCME, 1999).

Carlson trophic state index (Carlson, 1977) was adopted to assess the trophic status of the marsh using three variables, namely chlorophyll a (TSI Chl.a $_{\text {, total phosphate }}$ (TSITP) and transparency $\left(\mathrm{TSI}_{\mathrm{SD}}\right)$.

Fishes were collected monthly from the three sites, using seine net $(120 \mathrm{~m}$ length with mesh sizes $10 \times 10$ and $5 \times 5 \mathrm{~mm})$, cast net $(9 \mathrm{~m}$ diameter with $15 \times 15 \mathrm{~mm}$ mesh sizes) and electro-fishing gear. All fish were counted and classified to species following Carpenter et al. (1997) and Coad (2010). Fish species identified and counted to calculate their composition in fish community. To each fish species, geographic origin (native or migratory or alien), trophic guilds and environmental degradation tolerance were assigned based on information from literatures (Mohamed et al., 2008, 2012; Coad, 2010; Mohamed and Hussain 2012a, b; Hussain, 2014).

The analysis of the nature of the fish assemblage in the three sites was carried out by the following methods and indices: relative abundance (Odum, 1970), the diversity index (Shannon and Weaver 1949), the evenness index (Pielou, 1977), and the richness index (Margalef, 1968).

The Index of Biotic Integrity (IBI) methodology presently being used in the study was modified from Minns et al. (1994) to meet the regional conditions of the marsh, who scored metrics from 1 to 10 . Sixteen metrics were chosen to calculate the integrated biological index depending on species richness, species composition and trophic guilds. Scores for metrics that increase with environmental quality included numbers of native, common native and migratory fish species, percentage of individuals of migratory species, herbivore, carnivore and piscivore, in addition to species richness. Scores of metrics that increase with decreasing environmental quality included number of alien species and percentage of individuals of alien species, tolerance species, Paniliza abu, Carassius auratus, tilapia (Tilapia zilli and Oreochromis aureus), omnivore species and detrivore species. Standardized IBI metrics were summed to obtain an IBI score that varied continuously from 0 to 100 for the marsh and the month, for each metric. IBI scores are rated as very poor (0-20), poor (20-40), fair (40$60)$, good (60-80) and excellent (>80) (Minns et al. 1994). Analysis of variance (ANOVA) was used to assess the monthly IBI scores 
differences $(p \leq 0.05)$ among the southern marshes using SPSS software (version 11, 2001) statistical package.

\section{Results}

\section{1- Ecological factors}

Monthly changes in the mean values of the ecological factors in the three sites of East Hammar marsh are summarized in Figure 1. Water temperature varied from $14.6{ }^{\circ} \mathrm{C}$ in January to $31.7^{\circ} \mathrm{C}$ in August, while $\mathrm{pH}$ changed from 7.9 in July to 8.5 in February. Salinity fluctuated from 2.0\% in October and November to $9.7 \%$ in February and dissolved oxygen ranged from $6.2 \mathrm{mg} / \mathrm{l}$ in March and April to 10.2 $\mathrm{mg} / \mathrm{l}$ in December. The lowest value of transparency $(50.0 \mathrm{~cm})$ recorded in March and the highest value $(78.7 \mathrm{~cm})$ in December. Reactive nitrate changed from $6.8 \mu \mathrm{g}-\mathrm{N} / 1$ in October to $19.6 \mu \mathrm{g}-\mathrm{N} / 1$ in February. Orthophosphate varied from . $2 \mu \mathrm{g}-\mathrm{P} / 1$ in October to $1.7 \mu \mathrm{g}-\mathrm{P} / 1$ in February, while total phosphate ranged from $1.1 \mu \mathrm{g}-\mathrm{P} / 1$ in July and October to $2.4 \mu \mathrm{g}-\mathrm{P} / 1$ in February. Chlorophyll $a$ changed from $3.1 \mu \mathrm{g} / 1$ in August to $18.7 \mu \mathrm{g} / 1$ in March.

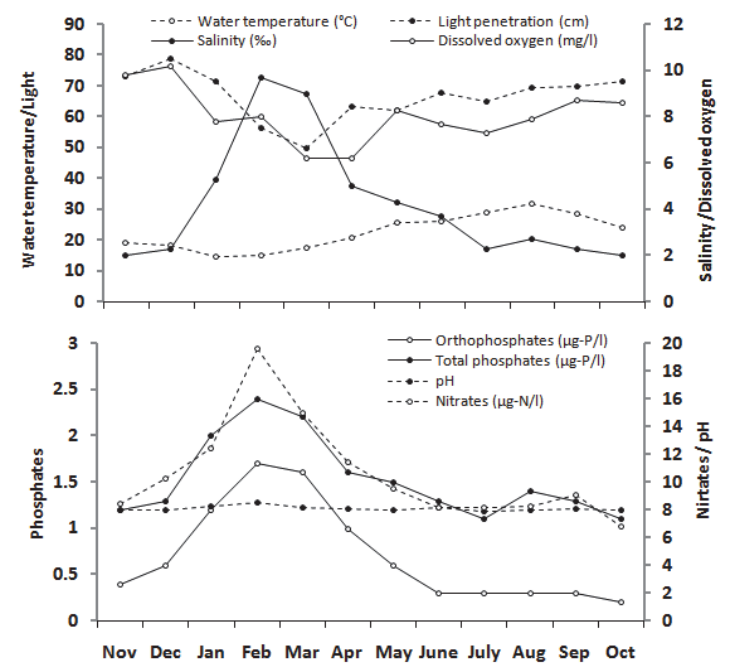

Fig. 2. Monthly variations in the some ecological factors of East Hammar marsh (2012- 2013)

\section{2- Water Quality Index (WQI)}

The descriptive statistics for calculation of CCME-WQI in East Hammar marsh is presented in Table 1. A comparison of the various scopes (F1), frequencies (F2), and amplitudes (F3) values provides a synopsis of how the WQI varied from time to time. The number of tested data for each season was 42 out of which 25 and 13 were failed for data before desiccation during wet and dry season, respectively. Similarly 19 and six were failed for data after inundation during both seasons, respectively. The lowest values of F1, F2 and F3 are observed during dry season for data after inundation due to lower values of failed variables, percentage of individual failed tests and the amount by which they failed. Salinity was failed test (deviated) from their values in all cases compared with other ecological variables.

The values of WQI during the wet and dry seasons were 42.2 (poor) and 68.4 (fair), respectively based on data before desiccation, while the values were 48.0 (marginal) and 87.6 (good) during the wet and dry seasons, respectively based on data after inundation. The annual value of water quality index of the marsh during the study period varied from 51.1 (marginal) for data before desiccation to 67.8 (fair) for data after inundation.

Table 1. Summary statistics for calculation of WQI scores in the study area

\begin{tabular}{|l|c|c|c|c|}
\hline & \multicolumn{2}{|c|}{$\begin{array}{c}\text { Before } \\
\text { desiccation }\end{array}$} & \multicolumn{2}{c|}{ After inundation } \\
\hline $\begin{array}{l}\text { Term of the } \\
\text { Index }\end{array}$ & $\begin{array}{c}\text { Wet } \\
\text { Season }\end{array}$ & $\begin{array}{c}\text { Dry } \\
\text { Season }\end{array}$ & $\begin{array}{c}\text { Wet } \\
\text { Season }\end{array}$ & $\begin{array}{c}\text { Dry } \\
\text { Season }\end{array}$ \\
\hline $\begin{array}{l}\text { Total number of } \\
\text { variables }\end{array}$ & 7 & 7 & 7 & 7 \\
\hline $\begin{array}{l}\text { Number of } \\
\text { failed variables }\end{array}$ & 5 & 3 & 5 & 1 \\
\hline $\begin{array}{l}\text { Total numbers } \\
\text { of test }\end{array}$ & 42 & 42 & 42 & 42 \\
\hline $\begin{array}{l}\text { Number of } \\
\text { failed tests }\end{array}$ & 25 & 13 & 19 & 6 \\
\hline$\sum$ excursion & 29.85 & 7.10 & 18.94 & 3.14 \\
\hline $\begin{array}{l}\text { Nse (normalized } \\
\text { sum of } \\
\text { excursions) }\end{array}$ & 0.71 & 0.17 & & \\
\hline F1 (Scope) & 71.43 & 42.86 & 71.43 & 14.29 \\
\hline F2 (Frequency) & 59.52 & 30.95 & 45.24 & 14.29 \\
\hline
\end{tabular}




\begin{tabular}{|l|c|c|c|c|}
\hline F3 (Amplitude) & 41.54 & 14.47 & 31.07 & 7.50 \\
\hline CCME-WQI & 42.2 & 68.4 & 48.0 & 87.6 \\
\hline
\end{tabular}

\section{3- Trophic state index (TSI)}

Monthly variations in the mean values of TSI $_{\text {Chl.a, }}$ TSI $I_{\mathrm{TP}}, \mathrm{TSI}_{\mathrm{SD}}$ and Carlson trophic state index (CTSI) of East Hammar marsh are illustrated in Figure 3. The mean values of, TSI $_{\mathrm{TP}}, \mathrm{TSI}_{\mathrm{Chl} . \mathrm{a}}$ and $\mathrm{TSI}_{\mathrm{SD}}$ were $9.7,49.8$ and 66.5 , respectively. The value of trophic state index was fluctuated from 38.6 in August and the marsh classified as oligotrophic to 48.3 in March and the marsh classified as mesotrophic.
The marsh was evaluated to be mesotrophic $(\mathrm{CTSI}=42.0)$.

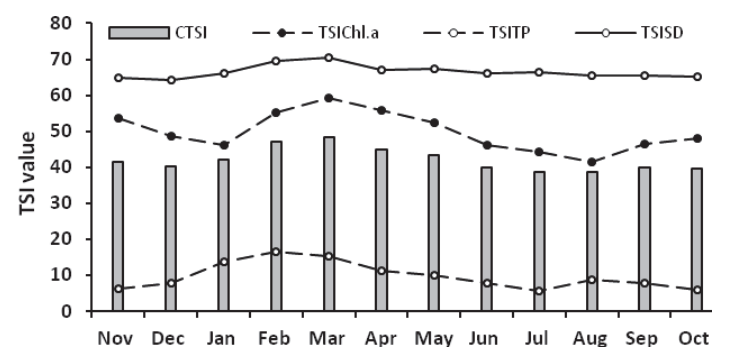

Fig. 3. Monthly variations in the trophic state index of East Hammar marsh

Table 2. Relative abundance (\%) of fish species caught in East Hammar marsh during 2012-2013

(1= Herbivore, $2=$ Omnivore, $3=$ Carnivore, $4=$ Detrivore, $5=$ Piscivore, $6=$ Tolerant, $7=$ Sensitive $)$

\begin{tabular}{|c|c|c|c|c|c|}
\hline Native species & $\%$ & Migratory species & $\%$ & Alien species & $\%$ \\
\hline Palniliza $a b u^{4,6}$ & 13.4 & Thryssa whiteheadi ${ }^{2,6}$ & 7.0 & Carassius auratus $^{2,6}$ & 21.2 \\
\hline Alburnus mossulensis ${ }^{3,6}$ & 3.8 & Tenualosa ilisha $a^{2,6}$ & 3.6 & Poecillius latipinna $^{2,6}$ & 14.3 \\
\hline Acanthobrama marmid ${ }^{3,6}$ & 3.5 & Thryssa hamiltonii ${ }^{2,6}$ & 2.7 & 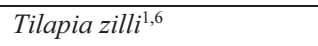 & 5.1 \\
\hline Aphanius dispar ${ }^{3,6}$ & 3.4 & Thryssa vetrirostris ${ }^{2,6}$ & 2.4 & 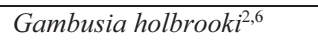 & 2.9 \\
\hline Aphanius mento ${ }^{3,6}$ & 1.7 & Bathygobius fuscus $^{2,6}$ & 1.9 & Oreochromis aureus $^{1,6}$ & 2.9 \\
\hline Aspius vorax ${ }^{5,7}$ & 0.9 & Palniliza subviridis $^{4,6}$ & 1.7 & Hemiculter leucisculus $^{1,6}$ & 1.9 \\
\hline Silurus triostegus ${ }^{5,7}$ & 0.8 & Palniliza klunzingeri ${ }^{4,6}$ & 1.4 & Cyprinus carpio $^{2,6}$ & 0.5 \\
\hline Carasobarbus luteus ${ }^{1,7}$ & 0.7 & $\begin{array}{l}\text { Acanthopagrus } \\
\text { arabicus } \\
2,6\end{array}$ & 0.6 & Heteropneustus fossilis ${ }^{2,6}$ & 0.03 \\
\hline $\begin{array}{l}\text { Mesopotamichthys } \\
\text { sharpeyi }^{1,7}\end{array}$ & 0.02 & Nematalosa nasus ${ }^{2,6}$ & 0.4 & Ctenophryngodon idella ${ }^{1,6}$ & 0.01 \\
\hline $\begin{array}{l}\text { Mastacembelus } \\
\quad \text { mastacembelus } \\
5,7\end{array}$ & 0.02 & $\begin{array}{l}\text { Boleophthalmus } \\
\text { dussumieri }{ }^{2,6}\end{array}$ & 0.4 & - & - \\
\hline Mystus pelusius $^{3,6}$ & 0.01 & $\begin{array}{l}\text { Hyporhamphus } \\
\text { limbatus }^{2,6}\end{array}$ & 0.3 & - & - \\
\hline- & - & Leiognathus bindus ${ }^{2,6}$ & 0.2 & - & - \\
\hline- & - & Acanthopagrus berda $a^{2,6}$ & 0.1 & - & - \\
\hline- & - & Johnius belangerii ${ }^{2,6}$ & 0.1 & - & - \\
\hline- & - & Brachirus orientalis $^{2,6}$ & 0.1 & - & - \\
\hline- & - & Sillago sihama ${ }^{2,6}$ & 0.1 & - & - \\
\hline- & - & Ilisha compressa ${ }^{2,6}$ & 0.1 & - & - \\
\hline- & - & Sparidentex hasta ${ }^{2,6}$ & 0.001 & - & - \\
\hline- & - & Sardinella albella ${ }^{2,6}$ & 0.001 & - & - \\
\hline
\end{tabular}

\section{4- Ecological indices and IBI}

The fish species composition, geographic origin (native, migratory or alien), trophic guilds and environmental degradation tolerance of fish captured from the East Hammar marsh during the study period are given in Table 2 . Thirty nine of osteichthyes species were obtained, 11 of them were native, nine alien and 19 marine species. The abundances of native, alien and marine species were $28.2,23.0$ and $48.8 \%$ of the total catch, respectively. C. auratus was the most abundant species comprising $21.2 \%$ of the total numbers followed by Poecillius latipinna (14.3\%) and P. abu (13.4\%). 
Monthly variations in the diversity, richness and evenness indices of fish species in the marsh are shown in Figure 3 . The diversity index fluctuated from 1.95 in December 2009 to 2.74 in September, with overall value 2.29. The richness indices changed from 2.32 in February to 3.81 in September, with overall value 2.95 . The evenness index ranged from 0.69 in December to 0.84 in September, with overall value 0.76 .

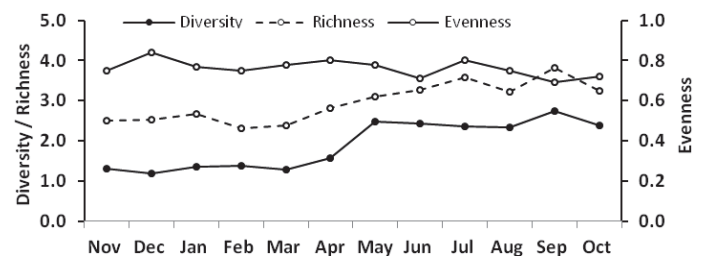

Fig. 3. Monthly variations in the ecological index values of East Hammar marsh

The monthly variations in IBI values of different metrics of fish assemblage in the marsh during the study period are plotted in Figure 4. IBI score of the number of native fish species ranged from 6.7 in February to 10 in April, June and September, whereas, the IBI score of migratory fish fluctuated from 2.2 in December and January to 10 in September. The maximum IBI score of alien fish species was 2.5 in February and March, and dropped to zero during April, June, July and September. IBI score of species richness ranged from 6.1 in February to 10 in September (Fig. 4a). The maximum IBI scores of common native species and percentage of migratory fish were recorded in September and October, respectively. The highest IBI scores of percentage of alien and tolerant species were 3.82 and 1.04 recorded in October and April, respectively (Fig. 4b). The maximum IBI scores of percentages of herbivorous, omnivorous and detrivorous were in September, whereas of carnivorous and piscivorous were in October and November, respectively (Fig. 4c). The highest IBI values for $C$. auratus, $P$. abu and tilapia species were 9.0, 7.8 and 9.3 recorded in October, September and November, respectively (Fig. 4d).

The monthly variations in the total IBI score of fish assemblage in the marsh during the study period is shown in Figure $4 \mathrm{~d}$. The IBI values varied from 37.0 in December and classified as poor to $61.0 \mathrm{in}$ September and considered as good. The values of IBI were fair during the rest of the year. The overall IBI value of the marsh was evaluated to be fair $(47.7 \%)$ during 2013-2014.

The overall F-IBI was significantly positively correlated with water temperature $(\mathrm{r}=0.62, \mathrm{p} \leq 0.05)$, diversity index $(\mathrm{r}=0.82, \mathrm{p} \leq 0.05)$ and richness $(\mathrm{r}=$ $0.79, p \leq 0.05)$, and negatively correlated with salinity $(\mathrm{r}=-0.41, \mathrm{p} \leq 0.05)$.

\section{Discussion}

The overall objective of water quality monitoring programs is to inform people about the suitability of water for various beneficial uses in both the spatial and temporal domains. The key concern in setting specific objectives for monitoring programs is to ensure that the right questions are being asked about the water quality issue of interest. People want to know if their water is clean and safe to use, and if water quality is getting better or worse, i.e., trends (Water Quality Task Group 2006).

The deterioration of the WQI of the marsh during the wet season compared with the dry season, which recorded the 
highest values and classified the marsh as fair to good quality, contrasts with other studies that referred to improved water quality in the winter as a result of rainfall and thus increase the water level and improved the quality of the water (Khadka and Khanal 2008). However, Al-Shujairi (2013) mentioned that the WQI in wet season for Tigris and Euphrates rivers was slightly less than in dry season due to engineering control on the rivers have greatly reduced their seasonality.

The inundation rate of the marsh in the province of Basra was gradual increased during wet season, reaching $66 \%$ and $81 \%$ during November and December 2012, respectively and raised to $91 \%$ in January 2013 (Ministry of Water Resources 2013). This sudden rise in the inundation rate was due to excessive discharged of water to West Hammar marsh from Euphrates River and to heavy rains led to runoff water from dried

and agricultural lands between the two parts of Hammar marsh toward the East part. In addition to the discharge of drainage water from the Main Outfall Drain into the West Hammar marsh through Al-Kamisia outlet, which contained high concentration of total dissolved solids, nitrates and phosphates (Frenken, 2009). These significant reasons have seriously diminished water quality during wet season.

The study revealed that the water quality of East Hammar marsh was fair (WQI = 67.8) based on data after inundation and was better than the state of the marsh during 2005-2006, WQI= 37.2 (AL-Saboonchi et al., 2011). However, Hussain et al . (2011) reported that the WQI of East Hammar marsh improved in 2007 (WQI= 60) in comparison with previous years, but declined again in 2008 $(\mathrm{WQI}=56)$ as resultant of decreased discharge of Tigris and Euphrates Rivers during 2008 on the contrary to 2006 .

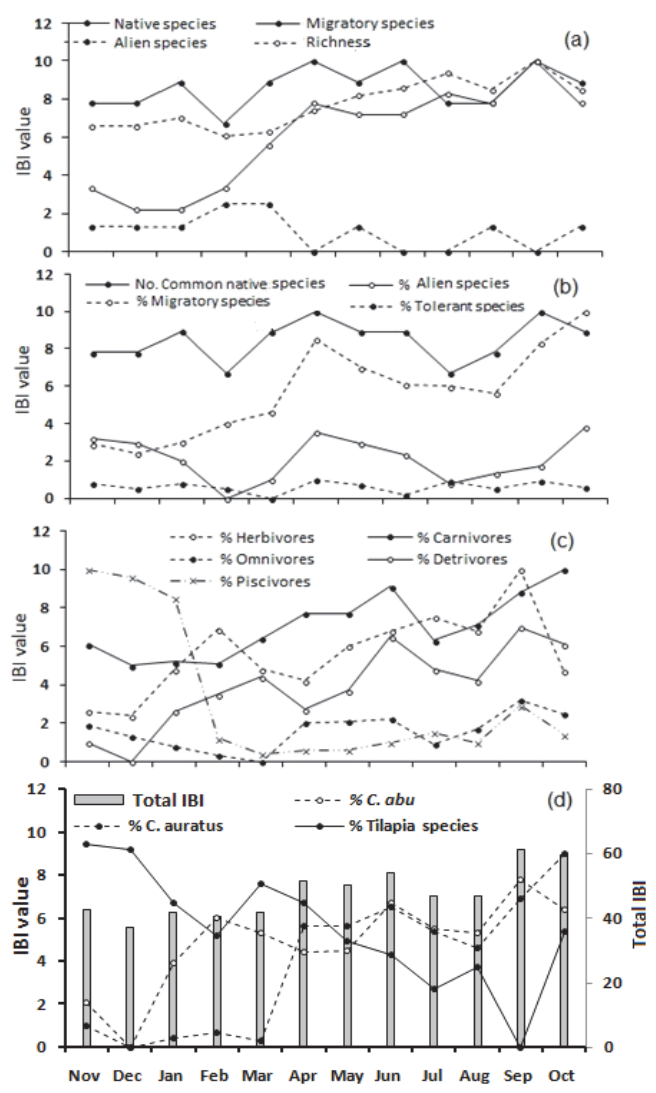

Fig. 4. Monthly variations in IBI scores metrics in East Hammar marsh (2013-2014)

Trophic state is often used to classify aquatic ecosystems according to biotic productivity and is a fundamental property that is intimately related to both ecosystem structure and how humans influence water quality (Dodds and Cole 2007). Sandeep et al. (2008) have found that TSI as an important aspect in lake survey, water quality and this can be used as a tool to measure trophic state where the biomass is involved. The increase of nitrate and phosphate concentrations during the wet season in this study, especially phosphate, which are one of the 
factors that affect the phytoplankton community (Harnstrom et al., 2009) have contributed to an increase of chlorophyll $a$ level of a comparison with studies before desiccation, which ranged between 0.15 to $8.4 \mathrm{mg} / \mathrm{l}$ (Al-Lammi, 1986; Al-Araji, 1988; AL-Saadi and AL-Lammi 1992), and also after inundation, which varied from 1.6 to $18.4 \mathrm{mg} / 1$ (ARID, 2006). This may increase the value of $\mathrm{TSI}_{\mathrm{Chl}}$.a in the marsh. Chlorophyll $a$ in this study showed positive correlations with nitrates $(\mathrm{r}=$ $0.481, \mathrm{p}<0.05)$, active phosphate $(\mathrm{r}=$ $0.624, \mathrm{p}<0.05)$ and total phosphorus $(\mathrm{r}=$ $0.520, \mathrm{p}<0.05)$. Xie et al. (2003) reported persistent coincidence between the occurrence of algal bloom and that of phosphorus. The main parameter in deciding the trophic status of an aquatic water body is its phosphorus concentration; any change in phosphorus concentration of fresh water ecosystem can also alter its trophic status (Devi Prasad and Siddaraju 2012).

The result of the trophic state index suggested that the East Hammar marsh was evaluated to be mesotrophic state. This finding agreed with the trophic state of the marsh after inundation (ARID, 2006), and with Al-Huwaza marsh during 2006 (Ziboon and AL-Zubidy 2010).

There were seasonal changes in fish diversity and richness indices and the general tendency was high values during the period from April to October attributed largely to the penetration of marine species especially anadromous ones. The abundance of marine species led to an increase in richness, evenness and diversity indices and created seasonal fluctuation in relative abundance and total number of individuals. This was comparable to the previous studies on the
East Hammar marsh (Hussain et al., 2009; Mohamed et al., 2009, 2014), but the values of indices were higher in the present study. McErlean et al. (1973) considered a wide range of richness index as an indicator of the nursery function of an area. Also, there was a narrow range in evenness values of the fish assemblages in this study, which indicates the lack of a dominant species (Smith and Wilson 1996).

The Index of Biotic Integrity (IBI) provided a tool for quantifying changes in ecosystem health as a result of habitat degradation or flow alteration, in addition to chronically poor chemical water quality (Karr and Dudley 1981). The decline in FIBI scores during the wet season in this study was largely attributable to higher percentages of exotic and tolerant species, as a result of deterioration water quality during this season due to runoff water from dried and agricultural lands and the discharge of drainage water from the Main Outfall Drain. The extremely tolerant species are the last to disappear in response do environmental degradation (Bozetti and Schulz 2004; Costa and Schulz 2010). Seilheimer and ChowFraser (2006) mentioned that a large number of tolerant species could result in a higher diversity score for degraded sites, and this may explain why species richness was negatively correlated with WQI score. The number of fish species supported by an undisturbed aquatic ecosystem decreases with environmental degradation, as intolerant species will disappear with increasing disturbance (Karr et al., 1986). However, the improvement of F-IBI values during the dry season was associated with increase of metrics scores that increase with improving environmental quality, 
included richness index, numbers of native and migratory marine fish species, and percentage of individuals of migratory, herbivore and carnivore species (Brousseau and Randall 2008).

The ecological status of the marsh was found to be fair $(\mathrm{F}-\mathrm{IBI}=47.7)$ and was slightly better than the status of the marsh after 2-4 years of restoration activities, F -IBI= 42.6-44.5 (Mohamed and Hussain, 2012a; Al-Shamary, 2008) and Chybaish marsh, F-IBI= 45.6 (Mohamed, 2014). The reasons for this simple improvement, despite the low number of native species and the high number of exotic species recorded, was attributed to the high value of richness index, high proportions of marine and carnivores species, in addition to a decrease in the proportions of $C$. auratus, $P$. $a b u$ and detrivores species in the fish assemblage.

The rather low improvement in the situation of the marsh indicates that the environment is still fragile and requires the allocation of water share from the Tigris and Euphrates rivers to restore marsh normality.

\section{References}

Al-Ararji, M. J. (1988) An Ecological Study on Phytoplankton and Nutrients in Al-Hammar Marsh-Iraq. M.Sc. Thesis, University of Basrah, Iraq.

Al-Kenzawi, M. A. H., Al-Haidary, M. J. S Talib, A. H. and Karomi, M. F. (2011) Environmental study of some water characteristics at Um-AlNaaj marsh, south of Iraq. Baghdad Sci. J., 8 (1): 531-538.

Al-Lami, A. A.1986. An Ecological Study on the Phytoplankton in the Southern, Iraq. M.Sc. Thesis, University of Basrah, Iraq.

Al-Saadi, H. A. and Al-Lami, A. A. (1992) Seasonal variation of phytoplankton in some marshes area in Southern Iraq. J. Coll. Educ. Women, Univ. Baghdad, 3:56-61.
AL-Saboonchi, A. A., Mohamed, A. M., AL-obaidy, A. M., Abid, H. S. and Maulood, B. K. (2011) On the Current and Restoration Conditions of the southern iraqi marshes: Application of the CCME WQI on East Hammar Marsh . J. Environmental Protectio, .2: 316-322.

Al-Shamary, A. C. (2008). Ecological assessment for South-East Al-Hammar marsh, north of Basrah. M.Sc. Thesis, University of Basrah, Iraq.

Al-Shujairi, S. O. H. (2013) Develop and apply water quality index to evaluate water quality of Tigris and Euphrates Rivers in Iraq. Int. J. Modern Eng. Res., 3 (4): 2119-2126.

APHA (American Public Health Association). (2005) Standard method for the examination of water and wastewater, $21^{\text {th }}$ ed. Washington, USA. 1193 $\mathrm{p}$.

ARDI. (2006) Final report 2005-2006 restricted distribution. Agriculture reconstruction and development program for Iraq. Marsh lands monitoring Team. $172 \mathrm{p}$.

Bowen, Z. H., Freeman, M. C. and Watson, D. L. (1996) Index of Biotic Integrity Applied to a Flow-Regulated River System. In: Proceedings of the 50th Annual Conference of the Southeastern Association of Fish and Wildlife Agencies, 1996: U.S. Fish and Wildlife, p. 2637.

Bozzetti, M. and Schulz, U.H. (2004) An index of biotic integrity based on fish assemblages for subtropical streams in southern Brazil. Hydrobiologia, 529: 133-144.

Brousseau, C. M., and Randall, R. G. (2008) Assessment of long-term trends in the littoral fish community of Hamilton Harbour using an Index of Biotic Integrity. Can. Tech. Rep. Fish. Aquat. Sci., 2811: ii +85 p.

Carlson, R. E. (1977) A trophic state index for lakes. Limnol. and Oceanogr., 22: 361-369.

Carpenter, K. E., Krupp, F., Jones, D. A. and Zajonz, U. (1997) FAO species identification field guide for fishery purposes. Living marine resources of Kuwait, Eastern Saudi Arabia, Bahrain, Qatar and the United Arab Emirates. FAO, Rome. 293 p.

CCME (Canadian Council of Ministries of the Environment). (1999) Canadian Water Quality Guidelines for the Protection of Aquatic Life. Canadian Environmental Quality Guidelines, Technical Subcommittee, Gatineau, 1999.

Coad, W. B. ( 2010) Freshwater Fishes of Iraq. Pensoft Publishers, Sofia, Bulgaria. 274p.

Costa, P. and Schulz, U. (2010) The fish community as an indicator of biotic integrity of the streams in the Sinos River basin, Brazil. Braz. J. Biol., 70: 1195-1205.

Devi Prasad, A. G. and Siddaraju. (2012) Carlson's Trophic State Index for the assessment of trophic 
status of two Lakes in Mandya district. Advanc. Appl. Sci. Res., 3 (5): 2992-2996.

Dodds, W. K. and Cole, J. J. (2007) Expanding the concept of trophic state in aquatic ecosystems: Its not just the autotrophs. Aquat. Sci. 69: 427439.

Frenken, K. (2009) Irrigation in the Middle East Region in Figures. AQUASTAT Survey 2008, Water Reports 34, Rome: FAO, ISBN 978-92-5106316-3).

Hameed, A. H. and Aljorany, Y. S. (2011) Investigation on nutrient behavior along Shatt Al-Arab River River, Basrah, Iraq. J. Appl. Sci. Res., 7: 1340-1345.

Härnström, K., Karunasagar, I. and Godhe, A. (2009) Phytoplankton species assemblages and their relationship to hydrographic factors-a study at the old port in Mangalore, coastal Arabian Sea. Indian J. Mar. Sci., 38(2): 224-234

Hassan, F. M. , Al-Kubaisi, A. A. and Talib, A. H. (2011) Phytoplankton primary production in southern Iraqi marshes after restoration. Baghdad Sci. J., 8(1): 519-530.

Hosmani, S. P. (2010). Trophic State Index in Conservation of lake ecosystems. Advanc. Plant Sci., 23(2): 593-596.

Hussain, N. A. (2014) Biolopes of Iraqi Marshlands. Dar Al-Fiker Publ. Dist. Basrah, Iraq. 432p.

Hussain, N. A., Mohamed, A. R. M., Al-Noor, S. S, Mutlak, F. M., Abed, I. M. and Coad, B. W. (2009) Structure and ecological indices of fish assemblages in the recently restored Al-Hammar Marsh, Southern Iraq. Bio Risk. 3: 173-186.

Hussain, N. A., Resin. A. K and Tahir. M. A. (2011) Water Quality Index (WQI) for three southern restored marshes (East Hammar, AL-Huwaza, Suq-AL-Shouykh) during the year 2005- 2008. In: Proc. $6^{\text {th }}$ int. Con. Biol. Sci. (Zool): 438-443.

Karr, J. R., Fausch, K. D., Angermeier, P. L., Yant, P. R. and Schlosser, I. J. (1986) Assessing biological integrity in running waters: A method and its rationale. Illinois Nat. Hist. Surv. Spec. Publ., 5, $28 \mathrm{p}$.

Karr, J. R. and Dudley, D. R. (1981) Ecological perspective on water quality goals. Env. Manag., 11: 249-256.

Khadka, R. B. and Khanal, A. B. (2008) Environment plan (EMP) for Melamchi water supply project Nepal. Environ. Monit. Assess. 146(1-3): 225234.

Lind, O. T. (1979) Handbook of common method in limnology. $2^{\text {nd }} e d$. The C.V. Mosby Co., St. Louis. $199 \mathrm{pp}$.

Maulood, B. K., Hinton, G. C. F, Kamees, H. S., Saleh, F. A. K., Shaban, A. A. and AlShahwani, S. M. H. (1979) An ecological survey of some aquatic ecosystems in southern Iraq. Trop. Eco1., 20: 27-40.

Margalefe, R. (1968) Perspectives in ecology. Univ. of Chicago. Press Chicago, USA.
McErlean, A. J., O`Connor, S. G., Mihurky, J. A. and Gibson, C. I. (1973) Abundance, diversity and seasonal patterns of estuarine fish populations. Estua. Coast. Mar. Sci. 1: 19-36.

Ministry of Water Resources. (2013) Tables of inundation rates of southern marshes, unpublished data. Ministry of Water Resources, Iraq.

Minns, C. K., Cairns, V. W., Randall, R. G. and Moore, J. E. (1994) An index of biotic integrity (IBI) for fish assemblages in the littoral-zone of Great-Lakes areas of concern. Can. J. Fish. Aquat. Sci. 51: 1804-1822.

Mohamed, A. R. M. (2014a) A Fish Index of Biotic Integrity for evaluation of fish assemblage environment in restored Chybaish marsh, Iraq. Global J. Biol. Agri. Health Sci., 3(1): 32-37.

Mohamed, A. R. M. (2014b) Evaluation of fish assemblage environment in Huwazah marsh, Iraq using Integrated Biological Index. Advanc. Agri. Biol., 1(3): 105-111.

Mohamed, A. R. M. and Barak, N. B. (1988) Seasonal Variations in Some Limnological Features of the Garma Marshes. Basrah J. Agri. Sci., 1(1): 5663.

Mohamed, A. R. M. and Hussain, N. A. (2012a) Evaluation of fish assemblage environment in east Hammar using Integrated Biological Index. Basrah J. Sci., 30(2): 87-105.

Mohamed, A. R. M. and Hussain, N. A. (2012b) Trophic strains and diet shift of the fish assemblage in the recently restored Al-Hammar marsh, southern Iraq. J. Univ. Duhok. 15(1): 119-127.

Mohamed A. R. M., Al-Saboonchi, A. A. and Raadi, F. K. (2014) Variability of fish assemblage structure in the East Hammar marsh, southern Iraq. JKAU: Mar. Sci., 25(2): 161-182.

Mohamed, A. R. M., Hussain, N. A., Al-Noor, S. S. and Mutlak, F. M. (2012) Ecological and biological aspects of fish assemblage in the Chybaish marsh, Southern Iraq. Ecohydrology \& Hydrobiology. 12(1): 65-74.

Mohamed, A. R. M., Hussain, N. A., Al-Noor, S. S., Coad, B.W. and Mutlak, F. M. (2009) Status of diadromous fish species in the restored East Hammar Marsh in Southern Iraq. Amer. Fish. Soc., 69: 577-588.

Mohamed, A. R. M., Hussain, N. A., Al-Noor, S. S., Coad, B.W., Mutlak, F. M., Al-Sudani, I. M., Mojer, A. M. and Toman, A. J. (2008) Species composition, ecological indices and trophic pyramid of fish assemblage of the restored AlHawizeh Marsh, Southern Iraq. Ecohydrology \& Hydrobiology. 8(4): 375-384.

Odum, W. A. (1970) Insidious alternation of the estuarine environment. Trans. Am. Fish. Soc., 99: 836-847.

Partow, H. (2001) The Mesopotamian Marshlands: Demise of an ecosystem. Nairobi (Kenya): 
Division of early warning and assessment, United Nation for Environmental Programs: UNEP publication UNEP/DEWA/, 103p.

Parson, T. R., Matia, Y. and Lalli, C. M. (1984) $A$ manual of chemical and biological methods for sea water analysis. Pergamon press. Oxford, $360 \mathrm{pp}$.

Pielou, E. C. (1977) Mathematical ecology. John Wiley, New York, 385pp.

Ramsar Convention Secretariat. (2013) The Ramsar Convention Manual: a guide to the Convention on Wetlands (Ramsar, Iran, 1971), 6th ed. Ramsar Convention Secretariat, Gland, Switzerland.

Richardson, C. J. and Hussain, N. A. (2006) Restoring the Garden of Eden: An ecological assessment of the marshes of Iraq. BioScience 56(6): 477-489.

Sandeep, B. M, Srikantaswamiy, S. and Hosmani S. P. (2008) The study of phytoplankton dynamics in two lakes of Mysore, Karnataka state. J. Nat. Env. Poll. Tech., 7(4): 300-306.

Seilheimer, T. S. and Chow-Fraser, P. (2006) Development and use of the Wetland Fish Index to assess the quality of coastal wetlands in the Laurentian Great Lakes. Can. J. Fish. Aquat. Sci. 63: $354-366$.
Shannon, C. E. and Weaver, W. (1949) The mathematical theory of communication. Univ. Illions. Press Urbane. 117pp.

Smith, B. and Wilson, J. B. (1996) A consumer's guide to evenness measures. Oikos 76(1): 70-82.

Tahir, M. A., Risena A. K. and Hussain, N. A. (2008) Monthly variations in the physical and chemical properties of the restored Southern Iraqi Marshes. Marsh Bull., 3 (1): 81-94.

UNEP/IMOS. (2007) Iraqi marshland observation system. United Nations Environmental Programme. Iraqi Marshlands Observation System, 35p.

Xie, L. Q., Xie, P. and Tang, H. J. (2003) Environment of dissolved phosphate release from sediment to lake water by Microcystis biomass- An enclosure experiment in a hyper eutrophic Chinese lake. Env. poll., 122: 391-399.

Water Quality Task Group. (2006) A Canada-wide framework for water quality monitoring. Canadian Council of Ministries of the Environment. July 2006. 29p.

Ziboon, A. T. and AL-Zubaidy R. Z. 2010. Remote Sensing model of monitoring Trophic state of AL- Huweizah marsh. Eng. Tech. J., 28 (16): 521-531. 


\section{تقييم بيئي لهور شرق الحمار ، العراق باستعمال عدد من الأدلة البيئية}

عبد الرزلق محمود محمد، أزهار علي الصابونجي، فادية خالد راضي

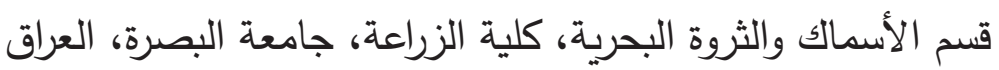

العستخلص. قيمت الحالة البيئية لهور شرق الحمار باعتماد عدد من الأدلة البيئية منها:

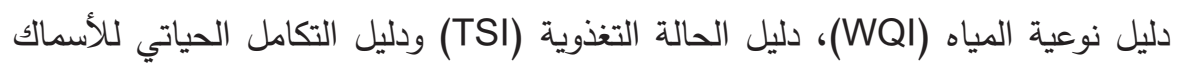

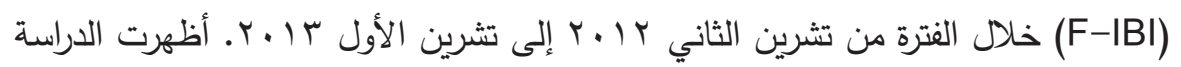

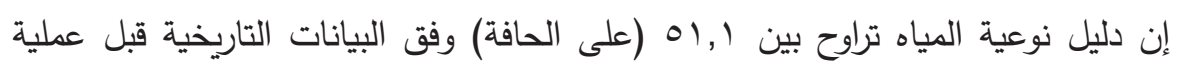

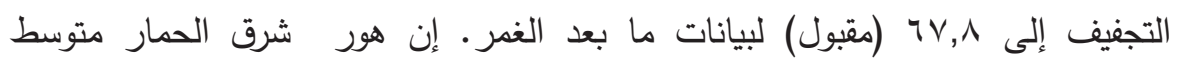

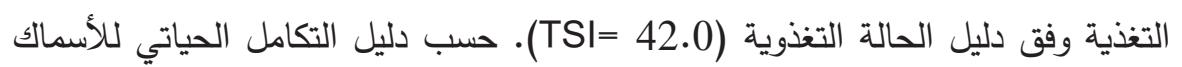
من 16 وحدة قياسية اعتدت على غنى وتركيبة وطبيعة غذاء أنواع تجمع الأسماك.

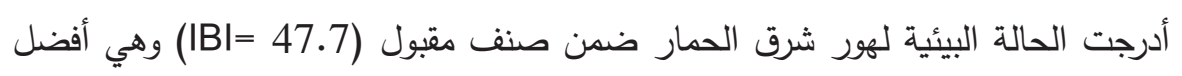

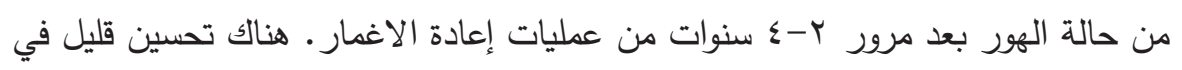

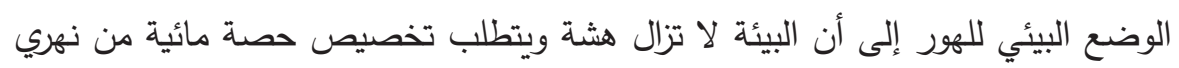
دجلة والفرات لاستعادة الهور طبيعته. 